\title{
Sikkerhedskopiering af truede kulturarvsmaterialer
}

\author{
UlLa BøgVad KeJseR*
}

I det følgende vil jeg opridse baggrunden for mit ph.d.-projekt og præsentere projektets problemstillinger og de teorier og metoder jeg arbejder med for at belyse dem. Projektet har arbejdstitlen 'Modellering af omkostninger og nytteværdi af forskellige tekniske løsninger for sikkerhedskopiering af truede kulturarvsmaterialer'. Jeg er indskrevet ved Konservatorskolen i København (2006-2009) og gennemfører projektet på $3 / 4$ tid. Ph.d.-stipendiatet samfinansieres af Kulturministeriet og Det Kongelige Bibliotek, hvor jeg også arbejder på $1 / 4$ tid som bevaringsspecialist $\mathrm{i}$ afdelingen for $\mathrm{Di}$ gital Bevaring.

\section{SIKKERHEDSKOPIERING}

Arkiver, biblioteker og museer (ABM institutioner) har tradition for at fremstille sikkerhedskopier af værdifulde arkivalier, bøger, kataloger, billeder, kort og andre kildematerialer. Det sker for at mindske risikoen for, at uerstattelige dele af kulturarven går tabt som følge af nedbrydning, brand, tyveri, eller andre katastrofer. Derfor stilles der høje kvalitetskrav til sikkerhedskopier: De skal gengive originalmaterialets information så autentisk som muligt, og de skal kunne bevares og gøres tilgængelige over tid.

Hidtil har man brugt analoge fotografiske optagelser på fx mikrofilm til sikkerhedskopi- ering af truede samlinger. $\mathrm{Da} A \mathrm{AB}$ institutioner i starten af 1990'erne begyndte at digitalisere deres samlinger var det med tilgængeliggørelse og formidling af kulturarven for øje. Digitale kopier blev ikke anset for at være egnede som sikkerhedskopier, fordi der ikke var udviklet tilstrækkeligt sikre metoder til langtidsbevaring af digitale materialer.

\section{ANALOG ELLER DIGITAL BEVARING AF SIK- KERHEDSKOPIER?}

I modsætning traditionelle materialer, som $\mathrm{fx}$ bøger, der kan læses med øjet, er digital information kun maskinlæsbar. Adgangen til digital information kræver for det første, at filen og det medie den er lagret på, er intakte og for det andet, at filformatet kan læses og fortolkes korrekt af maskinen, dvs. hardware og software systemet. Det kræver at man løbende overvåger filer og lagringsmedier for fejl, og udbedrer dem, så man undgår tab af information. Den hastige udvikling inden for informationsteknologien betyder, at der jævnligt kommer nye lagringsmedier, formater, programmer og operativsystemer på markedet, mens andre forældes og forsvinder. Floppydiske er et eksempel på et forældet lagringsmedie, ligesom filer genereret af tekstbehandlingsprogrammet 'Word Perfect', er et eksempel på et forældet filformat. Derfor er det også nødven- 
104 digt at overvåge de anvendte teknologier og gennemføre bevaringsindsatser, som fx migrering, før teknologierne forældes.

Digital bevaring kræver altså et system af strategier, forebyggende overvågning og aktive indsatser. Et system, der løbende skal tilpasses den teknologiske udvikling. Hvis man bare lagrer filerne, kan man ikke forvente, at de kan læses mere end få år.

De seneste års internationale forskning inden for digital bevaring har resulteret i udviklingen af forskellige tekniske løsninger for digital bevaring og begyndende etablering af sikre elektroniske magasiner.

Udviklingen inden for digital bevaring har gradvist forøget tilliden til, at man kan bevare digital information og bevirket, at mange $\mathrm{ABM}$ institutioner i dag overvejer at gå over til digitale sikkerhedskopier for at udnytte formidlingspotentialet. Institutionernes største

Eksempel på nedbrydningstruet cellulosenitratnegativ fra Sylvest Jensens Luftfotosamling. Negativet er fra 1952, men allerede meget sprodt og kraftigt misfarvet langs kanterne. Foto: Det Kongelige Bibliotek/FA.

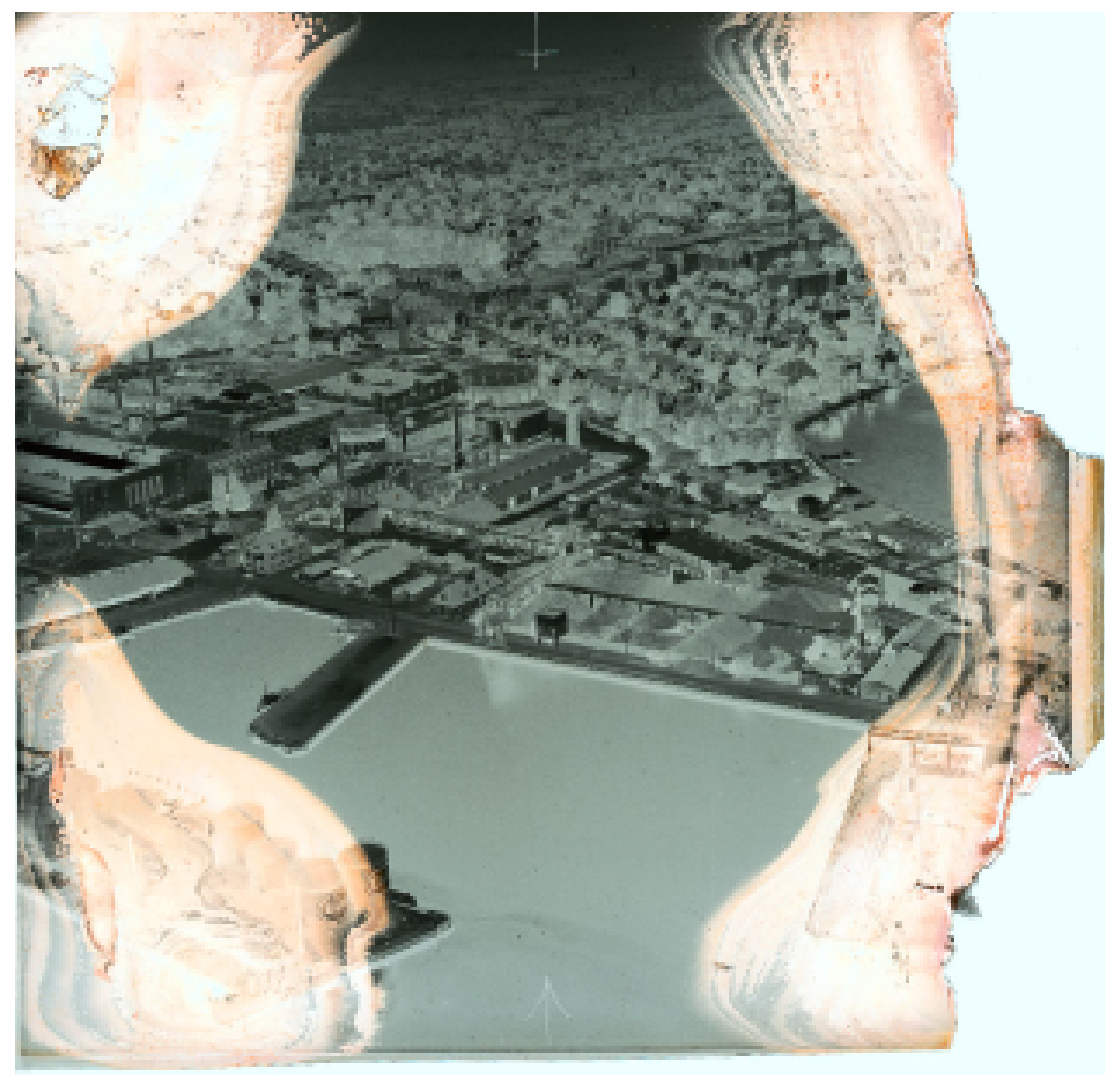


bekymring går i dag ikke så meget på, om det er teknisk muligt at bevare dataene men på, hvor meget det koster!

Netop omkostningerne ved digital langtidsbevaring har resulteret i udviklingen af en alternativ bevaringsstrategi: I stedet for at lagre de digitale filer elektronisk printes de ud på mikrofilm, såkaldt 'computer output microfilm' (COM), der bevares i traditionelle magasiner. Efter behov kan mikrofilmene hentes frem og enten læses direkte eller genindscannes, så kopierne gøres digitalt tilgængelige igen. Ekspeditionstiden er betydeligt længere for analoge film, og ud fra et bruger synspunkt er metoden derfor bedst egnet til samlinger med begrænset efterspørgsel.

I modsætning til traditionel bevaring, hvor man har velbeskrevne lagringssystemer og erfaringsbaserede omkostningsdata, er det vanskeligt at opgøre omkostningerne for digital bevaring, fordi systemerne stadig er under udvikling og etablering. Der er mangel på viden om, hvordan man opgør omkostningerne og på konkrete omkostningsdata. Generelt afhænger omkostningerne af datamængde, formater og bevaringssystemets strategiske og tekniske udformning, herunder af systemets sikkerhedsniveau. Fx er der langt større risiko for tab af data ved en simpel backup løsning end ved et egentligt bevaringssystem, men et back-up system er også betydeligt billigere.

Omkostningerne til bevaring er kun en del af omkostningerne ved sikkerhedskopiering. For at vurdere hvilken bevaringsstrategi, analog eller digital, man skal vælge, er man også nødt til at inddrage udgifterne til produktion og tilgængeliggørelse af sikkerhedskopier. Omkostningerne skal imidlertid også ses i lyset af de fordele, den nytteværdi, der er ved de forskellige løsninger.
MODELLERING AF OMKOSTNINGER OG

På de statslige ABM institutioner i Danmark dækkes udgifterne til bevaring af kulturarven primært af det offentlige. Kulturarven anses for et offentligt gode, som ABM institutionerne er forpligtigede til at bevare og formidle. Eftersom ressourcerne til bevaring er begrænsede, er det vigtigt, at de udnyttes effektivt og, at omkostningerne ikke overstiger samfundets nytteværdi. For at vurdere om man skal bevare sikkerhedskopier i et elektronisk magasin eller som udprint på COM i et traditionelt magasin, er det derfor relevant at vurdere løsningerne i et samfundsøkonomisk perspektiv. Hvilken nytte har en bevaringsindsats som sikkerhedskopiering for samfundet som helhed og mere specifikt, hvad er nytteværdien for brugere af den type kildemateriale, der sikkerhedskopieres?

Der findes forskellige økonomiske analysemetoder, som $\mathrm{fx}$ cost-benefit analyse (CBA) eller 'multikriterie analyse (MCA), til at sammenligne omkostninger og nytteværdi af alternative projekter og understøtte komplicerede beslutninger. CBA blev oprindeligt udviklet til vurdering af infrastrukturprojekter, fx motorvejs- og brobyggerier, og har siden spredt sig til miljøøkonomi og sundhedsøkonomi og senest også til kulturøkonomien. I modsætning til CBA hvor fordele og ulemper opgøres endimensionalt i kroner og ører, er der ved MCA mulighed for at sammenligne kriterierne flerdimensionalt. Inden for rammerne af et af disse værktøjer vil jeg opbygge en model, hvor alle omkostninger, fra vugge til grav, forbundet med sikkerhedskopiering analyseres og specificeres i forhold til forskellige kvalitetsniveauer for produktion, bevaring og adgang. Det der først og fremmest kompli- 
cerer opbygningen af modellen er, at systemerne til digital bevaring stadig er under udvikling. Derfor er et af målene med dette projekt at lave en omkostningsanalyse og en risikovurdering af et udvalg af bevaringssystemer, der har forskellig grad af sikkerhed indbygget.

Udover at kortlægge omkostningerne ved de to bevaringsløsninger skal de sættes i forhold til nytteværdien. Nytteværdien kan undersøges med forskellige teknikker, der afslører folks betalingsvilje, som fx et værdisætningsstudie 'contingent valuation'. Målet er at undersøge befolkningens almene vilje til at betale for bevaring af kulturarven gennem sikkerhedskopiering og mere konkret for brugeres betalingsvilje for kopier af kulturarvsmaterialer.

Modellen, der udvikles gennem litteraturstudier, eksperimentelt arbejde og gennem indsamling af data fra eksisterende samlinger (case studies), vil kunne bruges til at vurdere omkostninger og nytteværdi af forskellige strategier for sikkerhedskopiering. Den vil også kunne bruges til at analysere betydningen af ændringer i kvalitetskravene i forhold til økonomi og nytteværdi.

Ph.d. arbejdet er primært rettet mod det bevaringsfaglige forskningsfelt, hvor det skal bidrage med ny viden om strategier for bevaring af sikkerhedskopier af biblioteks- og arkivsamlinger. Eftersom projektet er tværvidenskabeligt og inddrager værktøj fra økonomisk teori og værdisætning af goder kan arbejdet også have interesse for fx økonomer og sociologer, der beskæftiger sig med værdisætning af kulturarven. Endelig kan projektet være af interesse for dataloger og andre IT specialister, som arbejder med digital bevaring

*Ulla Bøgvad Kejser, Konservatorskolen, København.

Adresse: Det Kongelige Bibliotek, Postboks 2149, DK-1016 København K, www.kb.dk Konservatorskolen, Esplanaden 34, DK-1263

København K, www.kons.dk E-mail:ubk@kb.dk 